A Multidisciplinary Publication of Centre for Research,

Maitreyi College, University of Delhi

April 2020, Volume 1, Issue 1

Original Research Article

\title{
A Comparative Analysis of Socio-Economic and Governance Dimensions of Political Regimes in India
}

\author{
Nidhi Chand, NupurKataria*, Anjali Kashyap, ArushiSood, Dhairya Sharma, Nikita Arora, \\ Shikha and Yogita Raj \\ Department of Economics, Maitreyi College, Chanakyapuri, New Delhi - 110021 \\ *Correspondence:nkataria@ maitreyi.du.ac.in
}

\begin{abstract}
The purpose of this paper is to concede the significance of good governance and socio-economic performance of different political regimes in India during the time period 1996-2018. The casual research design was employed using a quantitative approach to construct the Governance and socio-economic indices. In order to showcase how the different political parties performed in their respective years of power, the study pioneers in constructing a governance index using data on six worldwide governance indicators (WGI). These indicators seek to address the concerns of policymaking and public audiences by operationalizing such complex, multi-dimensional concepts as access to justice, corruption, and the rule of law, to name a few. A socio-economic index has been devised using various social justice and economic indicators to showcase the effectiveness of the respective ruling parties on the welfare aspect of the society. These indicators were adopted and collated from an array of sources that include governmental, civil society, and international development organizations.
\end{abstract}

Keywords: Good governance, Socio-economic parameters, Governance index, Socioeconomic index, Quantitative Approach, Policymaking.

\section{INTRODUCTION}

Governance as per the World Bank is defined as the manner in which power is exercised in managing the economic and social resources for development of a country (World Bank Report, 1992). Good governance is synonymous with sound development management. India has a large number of political parties as compared to other democratic countries. Over 200 political parties have been formed post-independence. However, there are mainly two political parties namely the Bhartiya Janata Party (BJP) and Indian National Congress (INC) which have been dominant. Also, according to the data available and used, it is known that the regime of 
the National Democratic Alliance (NDA) or BJP and alliance was during the period 1998-2004 and 2015-2018 and the regime of United Progressive Alliance (UPA) or INC and alliance was during the period 2005-2014. Different political parties when coming into power affect the GDP of a country in various ways. Each party has its own ideology and policies which influence the GDP in different ways. Therefore, it becomes essential to find out how the policies of a political party affect an economy and how it differs from other major political parties or alliances.

In modern times, good governance has become a catchphrase used widely by various international agencies such as the United Nations, the World Bank, and the International Monetary Fund (IMF). It means "governing well” by establishing a system of clean governance to achieve the anticipated goals and objectives of the public and the government. This paper focuses on how significantly do governance and change in the ruling party over time affect the overall performance of the nation both economically and socially in the context of the Indian economy. The objective of this paper is to first formulate a governance index (which is formed by combining six Worldwide Governance Indicators) and a socio-economic index (using various social indicators) to assess how they have performed during the time period of the study.

Good governance is the key to development and prosperity. It is a critical factor in achieving economic and social development objectives. However, the current challenges associated with good governance are unbearable due to factors such as corruption, conflict and bureaucratic bottlenecks. Good governance can be advanced and realized when it is well designed and practiced, when multiparty politics is well enforced, the state is held accountable, a free, fair and periodic election is conducted and human and political rights are respected. The second objective of the paper is to analyse and compare the data on various governance indicators and governance index during the time periods of NDA and UPA in order to showcase how the two parties performed in their respective years of power.

Today, governance and social justice are interrelated terms for the reason that man as the measure of all things has come to occupy the most important position in any concept of social justice in modern democracies. The creation of social justice means the creation of an environment in which every individual gets an unreserved and unhindered opportunity for physical and intellectual development. In removing disabilities arising from caste, sex, race, color, creed, religion or nationality and providing an opportunity in a positive way with a view to developing individual faculties, lies the essence of social justice. The term social justice implies a reordering of social life in such a manner that the material and moral benefits of social 
effort are not concentrated to a tiny privileged class but accrue to the masses to ensure the upliftment of the lower, weaker and underprivileged sections. To ensure justice in its true sense, the minimum requirement is of good governance which is transparent, accountable, effective and efficient, responsive and public-oriented in nature. To take this into account, the third objective of the paper is to analyse the data on socio-economic index using various social indicators such as level of education, birth rate, death rate, infant mortality rate, life expectancy, etc. and comparing the values of the socio-economic index during the regimes of NDA and UPA.

\section{LITERATURE REVIEW}

Many empirical studies have been done in the past which throw light upon the importance of economic and social development and of good governance on the overall development of the economy using cross-sectional, time series and panel datasets. Further, social, economic indicators and indicators affecting good governance have also generated numerous studies. These studies are not only country-specific but also cross country-oriented. Some of the studies are as follows:

Biadglign Dessie (2019) has examined the indicators of good governance and the extent to which these variables influence good governance. The indicators included educational level, corruption, bureaucracy, and conflict. The results of the paper revealed that all these variables have either a significant or moderate effect on good governance with the recommendations to improve governance.

Noha Emara (2016) in the research paper evaluated the governance impact on economic growth by using a set of 188 countries from the period 2009-2013. The indicators included six Worldwide Governance Indicators (WGI). The results of the paper suggest that no countries of the Middle East and North African (MENA) region showed a positive correlation between economic growth and governance.

Gisselquist (2012) in his research paper studied good governance and its effects on Development Policy which included democracy representation, rule of law, human rights, transparency and accountability, efficient and effective public management, particular institutions as the components of good governance in different countries supported by the multilateral development banks which concluded that promoting good governance is an important part of the development-related agendas of almost all major development institutions. However, good governance means different things to different organizations and also to different actors within these organizations. 
In their study, Miljkovic and Rimal (2008) used cross-country data on 122 countries for the period between 1960 and 1988. They tested the hypothesis that political instability is dependent on economic growth and its underlying economic and social determinants, as well as the nature of the political system present in the country. Their results confirmed that several socioeconomic factors including factors such as income growth rate, initial income level, and the nature of political regime affect political instability.

Edwin and Hussein (2001) in their research paper evaluated Real GDP and the influencing variables such as labor force, gross domestic investment, consumer price index, goods imports, import duty, public spending on education and import duty from the period of 1965-1997. The result of which explained that factors such as the natural rate of growth of the labor force, increased domestic investment, increased budgetary allocation to improve human capital, and open trade policies to encourage efficiency through use of better foreign technologies positively affect growth rate. However, the validity of this study would not apply to a particular country in the sample unless that country resembles closely the average country with respect to the economic structure as summarized by the values of the explanatory variables.

Pourgerami (1991) in his study took cross-country data on 106 developing countries in 1986 and using empirical results of a system of simultaneous equations supported the hypothesis that socio-economic development of a country facilitates democratic change and that countries with democratic political systems can achieve rapid economic growth. As per the author "The coexistence of poverty and lack of freedom in most developing countries should not constitute a 'cruel choice' between economic development and political democracy.'

\section{METHODOLOGY}

This section discusses the research design, methods, and procedures employed to conduct the study. It further describes the data collection methods and methods employed for data analysis and presentation.

\subsection{Data Collection Methods and Data Sources}

Data collection is any process of preparing and collecting data for process improvement or for a similar project. The purpose of data collection is to obtain information to keep en a record which would help make decisions about important issues. The study used secondary data from the electronic database available on the World Bank, the Reserve Bank of India (RBI) and the United Nations Development Programme (UNDP). The casual research design was employed using a quantitative research approach for this study. 


\subsection{Variables Under Study}

The variables that have been used to create governance and socio-economic index for the Indian economy are discussed below. Appendix presents a graphical representation of the trends observed in each of the variables.

a. Governance Index: It interrogates the overall performance of the central government in their respective regimes, the better the performance higher will be the economic growth, as we expect a positive and statistically significant relationship between the two [ REFER TO BOX 1].

It is constructed by taking an average of six Worldwide Governance Indicators (WGI). These indicators are constructed by an Unobserved Component Model (UCM). Also, these six indicators are reported in standard normal units with mean zero and standard deviation one, ranging from approximately -2.5 to 2.5 , where higher values correspond to better governance. The six WGI are as follows:

i. Voice and Accountability which measures the extent to which citizens of a country are able to participate in choosing their government, as well as freedom of expression, freedom of association, and free media (World Bank Report, 1992).

ii. Political Stability and Absence of Violence measuring realization of the chance that the government will be overthrown or destabilized by violent or unconstitutional means, including domestic violence and terrorism (World Bank Report, 1992).

iii. Government Effectiveness which measures the qualities of public services, civil service and the degree of its independence from political pressures, policy formulation and implementation, and the credibility of the government's commitment to formulate such policies (World Bank Report, 1992).

iv. Regulatory Quality which measures the government's ability to formulate and implement viable policies and regulations that allow and promote development of the private sector (World Bank Report, 1992).

v. Rule of Law which measures the extent to which citizens have confidence in and abide by the rules of economy, and particularly the quality of contract enforcement, the police, and the courts, and also the likelihood of crime and violence (World Bank Report, 1992)

vi. Control of Corruption which measures the extent to which public power is exercised for private gain, including all forms of corruption, and also control of the state by elites and private interests (World Bank Report, 1992) 
The time-series data has been collected from 1996-2018 for all the above variables and the data source is the World Bank. The index has been formulated using the UNDP method. ${ }^{1}$

b. Socio-economic index: The government has a pivotal role in ensuring social and economic development of the people it represents. Therefore, a socio-economic index is constructed by taking an average of various social and economic indicators which were normalized on a scale of 0 to 1 . The indicators used are as follows:

i. Proportion of seats held by women in national parliaments (\%); access to electricityrural(\% of rural population); access to electricity-urban (\% of urban population); domestic general government health expenditure per capita (current US dollars); school enrollment-pre-primary (\% gross); life expectancy at birth, (total years); people using at least basic sanitation services (\% of population) and Human Development Index. Higher the value of these variables, the higher is the social welfare of the country.

ii. Adolescent fertility rate (births per 1,000 women aged 15-19 years); prevalence of HIV, (total \% of population aged 15-49 years); vulnerable employment, total (\% of total employment); birth rate (per thousand); death rate (per thousand), infant mortality rate (per thousand); Unemployment, (total \% of total labour force). Lower the value of these variables, the higher is the social welfare of the country.

Again, the time-series data has been collected from 1996-2018 for all the above variables and the index has been formulated using the UNDP method. The data sources are the World Bank, Reserve Bank of India (RBI) and UNDP [REFER TO Appendix for graphs showing trends and patterns of individual variables].

Next, the aim of the paper is to analyze the economic performance of two central governments in their respective ruling time period; UPA (2005-2013) and NDA (1998-2004 and 20142018). Using various statistical measures of comparison, it can indisputably be shown which government performed superiorly well than the other over two decades. This will be done by carefully scrutinizing the values of the governance index and socio-economic index as discussed above.

\footnotetext{
${ }^{1}$ The indices have been calculated using the UNDP method. The indicators, which are in different units, are transformed into sub-indices by defining minimum and maximum values. Having defined the minimum and maximum values, the subindices are calculated as follows: Dimension index $=($ actual value - minimum value $) /($ maximum value - minimum value $)$.
} 


\section{RESULTS}

\section{1: Statistical Analysis of Governance Indicators and Governance Index}

The below-shown table (Table1) represents the maximum and minimum values of each of the six governance indicators as well as the governance index of UF (United Front), NDA, and UPA.

Table.1 Maximum and minimum values and range of governance indicators and governance index of UF, NDA and UPA

\begin{tabular}{|c|c|c|c|c|c|c|c|c|c|c|c|c|c|c|c|c|c|c|c|c|c|c|}
\hline & & \multicolumn{18}{|c|}{ Governance Indicators } & \multirow{2}{*}{\multicolumn{3}{|c|}{ Governance Index }} \\
\hline \multirow{2}{*}{\multicolumn{2}{|c|}{$\begin{array}{l}\text { Ruling } \\
\text { party }\end{array}$}} & \multicolumn{3}{|c|}{$\begin{array}{c}\text { Voice and } \\
\text { Accountability }\end{array}$} & \multicolumn{3}{|c|}{$\begin{array}{c}\text { Political Stability and } \\
\text { No Violence }\end{array}$} & \multicolumn{3}{|c|}{$\begin{array}{l}\text { Government } \\
\text { Effectiveness }\end{array}$} & \multicolumn{3}{|c|}{ Regulatory Quality } & \multicolumn{3}{|c|}{ Rule of Law } & \multicolumn{3}{|c|}{ Control of Corruption } & & & \\
\hline & & Minimum & Laximum & Range & Mnimum & Maximum & Range & Mininum & Maximum & Range & Uinimum & Maximum & Range & Minmum & Maximum & Range & Mnimum & Maximum & Range & Mininum & Maximum & Range \\
\hline \multirow[t]{2}{*}{ UF } & & 0.43 & 0.48 & 0.05 & -1.33 & -0.97 & 0.36 & -0.11 & -0.98 & 0.87 & -0.55 & -0.3 & 0.25 & 0.24 & 0.31 & 0.07 & -0.38 & -0.36 & -0.02 & -0.235 & -0.2033 & 0.315 \\
\hline & Year & 1997 & 1996 & & 1997 & 1996 & & 1996 & 1997 & & 1996 & 1997 & & 1997 & 1996 & & 1996 & 1997 & & 1997 & 1996 & \\
\hline \multirow[t]{2}{*}{ NDA } & & 0.35 & 0.45 & 0.3 & -1.51 & -0.83 & 0.68 & -0.16 & 0.09 & 0.25 & $-0,46$ & -0.16 & 0.3 & 0.05 & 0.35 & 0.3 & -0.52 & -0.24 & 0.28 & -0.3067 & -0.14 & 0.1667 \\
\hline & Year & 2000 & 2003 & & 2003 & 2017 & & 2004 & \begin{tabular}{|c|}
20178 \\
2018 \\
\end{tabular} & & 1998 & 2000 & & 2015 & 1998 & & 2002 & 2017 & & 2004 & 2017 & \\
\hline \multirow[t]{2}{*}{ UPA } & & 0.4 & 0.46 & 0.06 & -1.51 & -1.01 & 0.5 & -0.21 & 0.12 & 0.33 & -0.47 & -0.28 & 0.19 & -0.09 & 0.18 & 0.7 & -0.54 & -0.28 & 0.26 & -0.35167 & -0.1833 & 0.1684 \\
\hline & Year & 2012 & $\begin{array}{c}20088 \\
2009\end{array}$ & & 2007 & 2005 & & 2014 & 2007 & & \begin{tabular}{|c|}
20128 \\
2013 \\
\end{tabular} & 2006 & & 2011 & 2006 & & 2011 & 2006 & & 2012 & 2006 & \\
\hline
\end{tabular}

Represents maximum values

Represents minimum values

Before discussing Table 1 in detail, the paper has attempted to perform a small econometric exercise to formulate a simple linear regression model for Indian economy during the time period 1996-2018 to analyze the effect and statistical significance of governance index on India's economic growth. The results of the model and analysis are given in Box 1 .

The following observations have been made from the numerical values of various governance indicators as given in Table 1:

- Voice and Accountability was the highest in 1996 during the rule of the United Front and it was lowest in 2000 when NDA was at the center. This indicator of governance was stable under the regime of UPA as compared to NDA (Figure 5 in Appendix). The average voice and accountability was the lowest under NDA and highest under UPA (Figure 6 in Appendix).

- Political Stability and No violence were highest in 2017 when NDA was in power and it was lowest in 2003 under NDA as well as in 2007 under UPA. This indicator showed large fluctuations when NDA was in power from 1998-2004 (Figure 7 in Appendix). Average Political Stability and No Violence were maximum under NDA and minimum under UPA (Figure 8 in Appendix). 


\section{BOX 1: An Econometric Exercise}

The paper has estimated a linear time-series regression model for economic growth of Indian economy during the time period 1996-2018 using some past empirical studies to look at how economic growth is affected by the governance variable. The following results were obtained after performing various tests related to a time-series annual data and correcting the regression model accordingly:

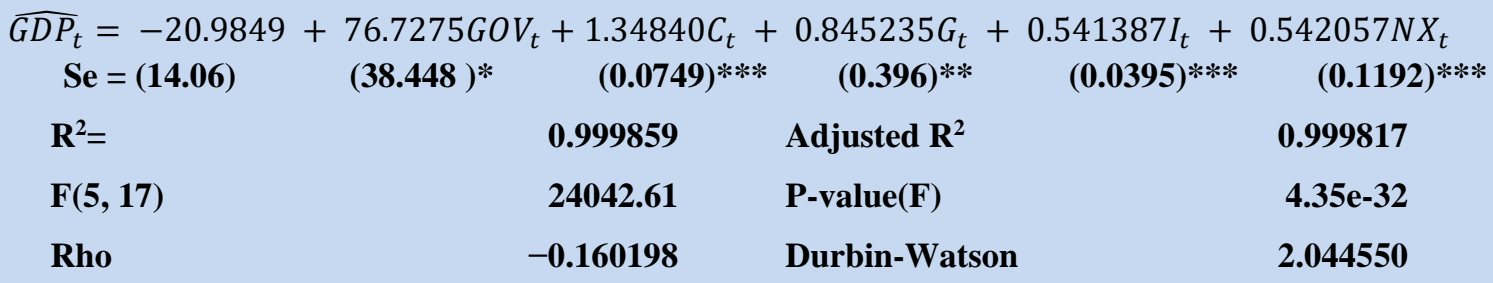

Where:

GDP: Gross Domestic Product measured at constant 2010 US\$ billion, C: Consumption Expenditure measured by Households and NPISHs Final consumption expenditure (constant 2010 US\$ billion), G: Government Expenditure measured by the General government final consumption expenditure (constant 2010 US \$ billion), I: Investment Expenditure measured by Gross capital formation (constant 2010 US \$ billion), NX: Net Exports measured at constant 2010 US\$ billion, GOV: Governance Index. Data Source: The World Bank.

NOTE: Standard errors are reported in parentheses; * significant at 10\%, ** significant at 5\% and **** significant at $1 \%$.

As the results indicate, Governance Index is found to have a positive and significant impact (statistically significant at 10\%) on GDP (which is taken as an indicator of economic growth) during the given time period. This emphasizes the fact that good governance does matter for economic development in the context of Indian economy.

- Government Effectiveness was at its peak in the year 2007 and lowest in 2017 during the regime of UPA. This indicator showed large fluctuations during the regime of UPA (Figure 9 in Appendix). The average government effectiveness was maximum under NDA and lowest under UPA (Figure 10 in Appendix).

- Regulatory quality was maximum under NDA in the year 2000 and lowest under UPA in the years 2012 and 2013. This indicator showed maximum fluctuations when UPA was at the center (Figure11 in Appendix). The average regulatory quality was highest under NDA and lowest under UPA (Figure 12 in Appendix).

- Rule of Law was highest in 1998 during the regime of NDA and lowest in 2011 during the rule of UPA. This indicator showed the maximum number of fluctuations under NDA during the time period of 1998-2004 (Figure 13 in Appendix). The average value 
of the rule of law was highest under NDA and lowest under UPA (Figure 14 in Appendix).

- Control of Corruption was maximum in 2017 under NDA and it was minimum in 2011 under UPA. This indicator showed maximum fluctuations under UPA (Figure 15 in Appendix). The average control of corruption was highest under NDA and lowest under UPA (Figure 16 in Appendix).

- Governance Index was maximum during the regime of NDA in 2017 and a minimum during the regime of UPA in the year 2012.

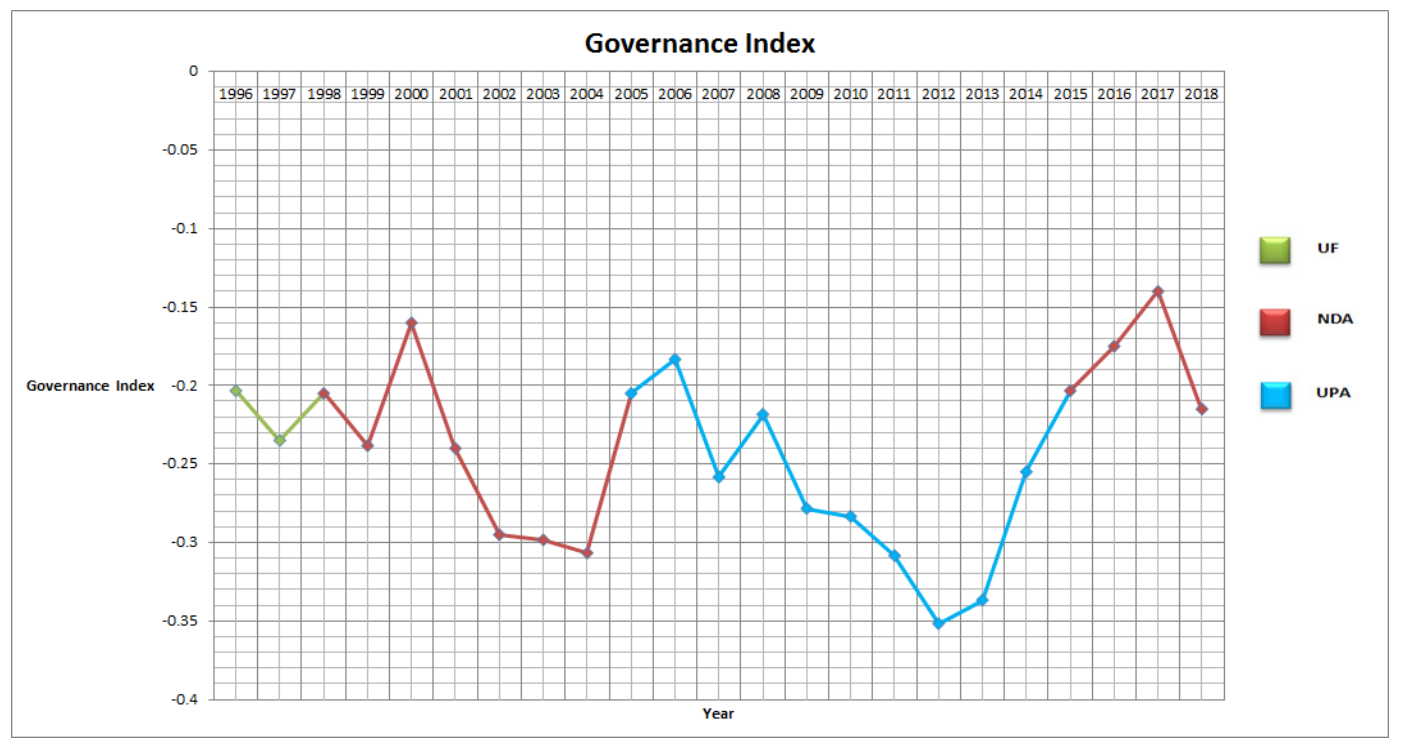

Figure 1: Governance Index

Figure 1 indicates that maximum fluctuations in the values of governance index were during the regime of UPA (2004-2014) as compared to NDA [(1998-2004) and (2014-2018)] and United Front (1996-1998).

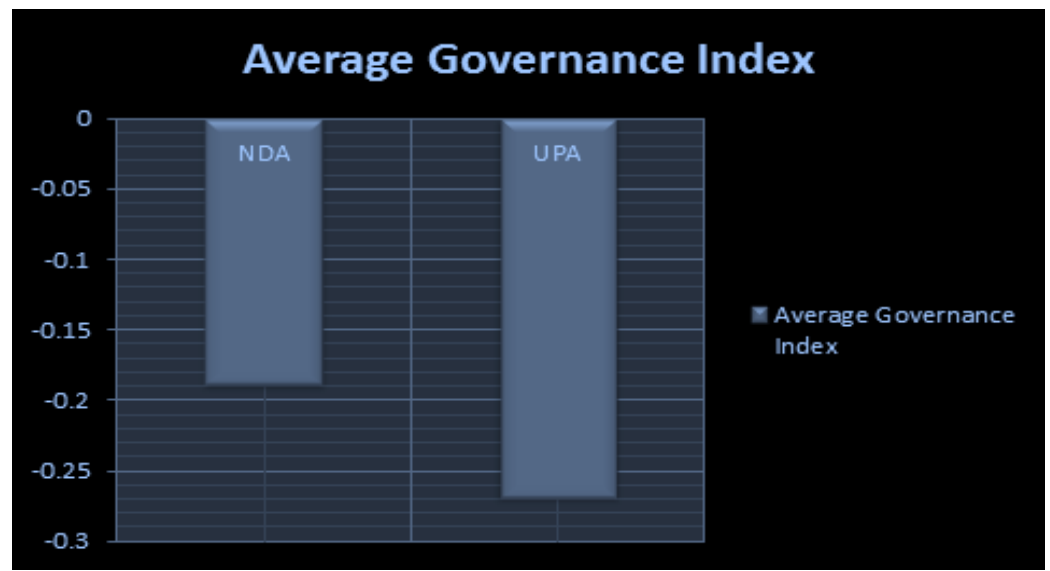

Figure 2: Average Governance Index 
Figure 2 suggests that the average governance index was highest under the regime of NDA and it was lowest under the UPA government.

\section{2: Statistical Analysis of Socio-economic indicators}

The following Figure 3 shows how the value of the socio-economic index changed during the time period 1996-2018. Figure 3 shows that the socio-economic index value has increased from 1996 till 2017. Its value is highest during the second term of the NDA from 2014 to 2017. The graph indicates that the socio-economic index of the economy has been increasing year by year due to better policy changes in this regard. The mean value of the socio-economic index is 0.4928 and its standard deviation is 0.2825 .

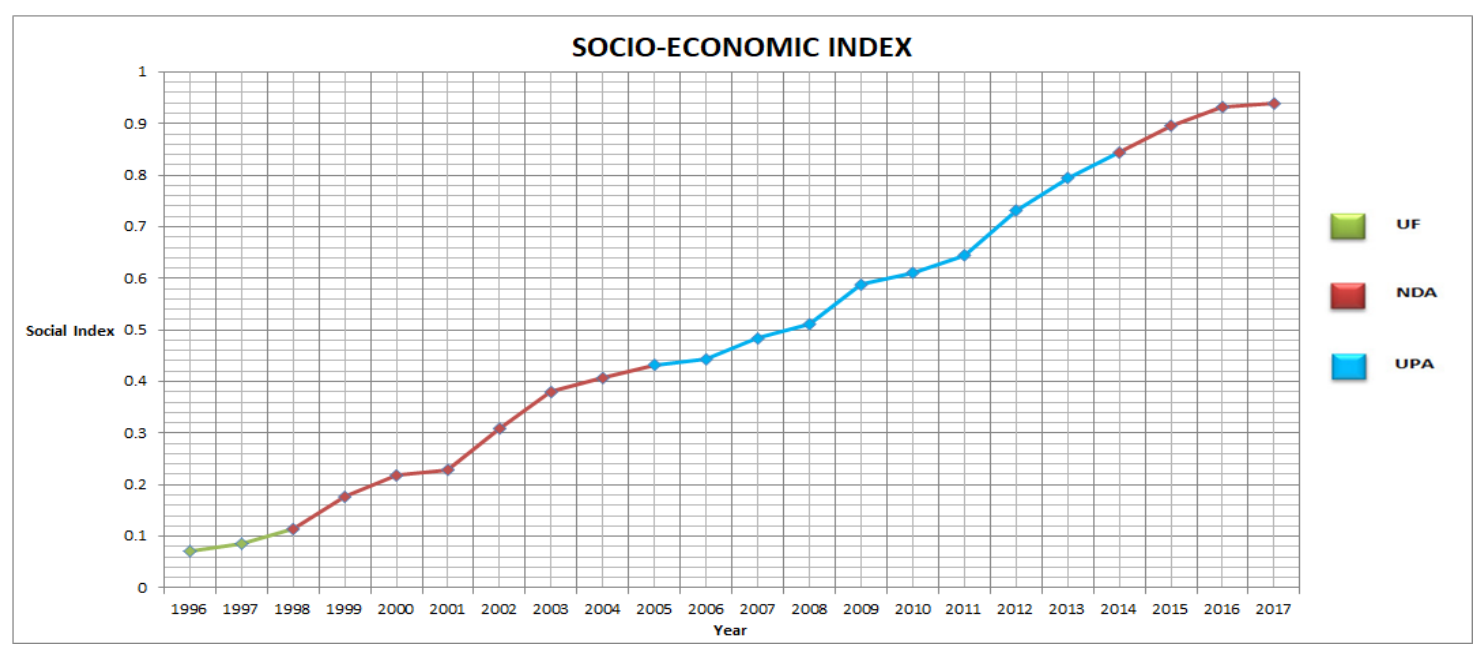

Figure 3: Socio-economic Index

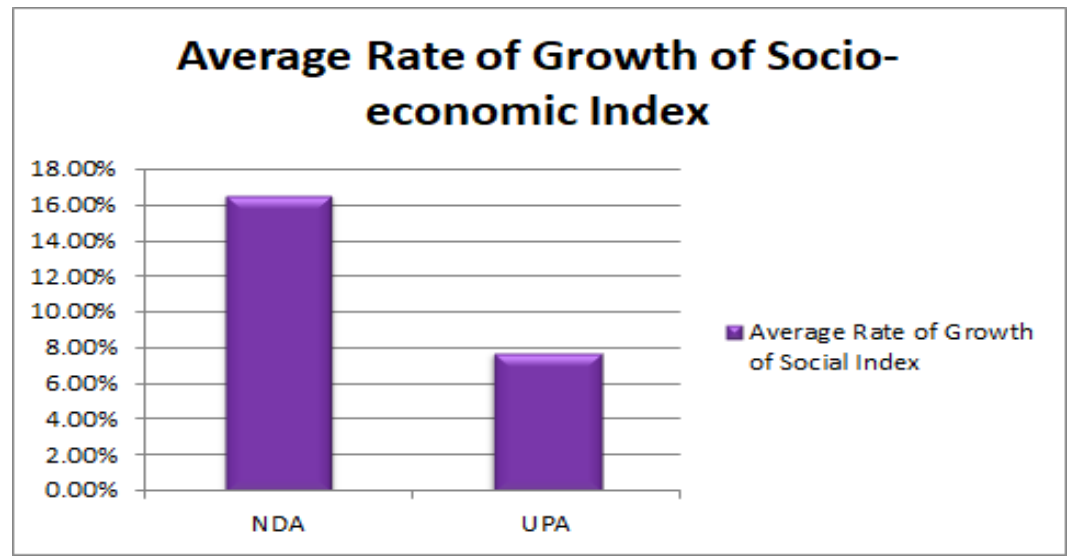

Figure 4: Average Rate of Growth of Socio-economic Index

The above Figure 4 shows that the average rate of growth of the socio-economic index has been highest during the regime of NDA and comparatively lower during the rule of UPA. 


\subsection{Ratiocinating the Results Discerned}

The reasons mentioned below might have played an important role in explaining the results observed in previous sub-sections:-

- The Rural Development Ministry witnessed a steady rise in spending under the NDA regime. MGNREGA, PM Awas Yojana, Swachh Bharat and PM Gram Sadak Yojana got top priority. As compared to 2014 where only 56\% of villages had road connectivity, more than $82 \%$ currently have been connected through roads (ETMarkets.com, 2019).

○ Another reason behind successes of the Modi government may have been on the inflation front. In May 2014, inflation, measured by the consumer price index (CPI), stood at $7.72 \%$, with food inflation at $9.21 \%$. In February 2019, inflation was at $2.57 \%$, with food prices falling by $0.66 \%$. While during $2018-2019$, food prices have risen by just $0.13 \%$ (Kaul, 2019).

- During the period between 2005 to 2013, the two UPA governments opened up more than 24 crore basic accounts, majority of which had zero balance and very little transaction activities. In contrast, the NDA government managed to open a similar number of accounts (nearly 23 crore) in less than two years. The Jan Dhan Yojana push seems to have a sharper focus and better concentration and managed to direct public sector banks towards serious financial inclusion (Srivas, 2016).

- As per the Union home ministry's reply to an RTI query based on communal riots in India during 2004 and 2017, the NDA regime seems to have fared better on all counts, such as the number of people killed and those injured and the number of incidents of communal violence. India recorded 10,399 incidents of communal violence from 2004 to 2017 when 1,605 people were killed and 30,723 injured, 3,858 incidents occurred between 2004 and 2008, this is a period that roughly coincided with the tenure of the UPA-1 and 3,621 communal riots occurred between 2009 and 2013, under the tenure of UPA-2. However, from 2014 to 2017, India witnessed a lower frequency of riots (2,920). Also, 1,216 people were killed every year between 2004 and 2013, that number fell to 97.25 a year under the NDA government (Rai, 2019).

○ The BJP-led NDA government has approved the construction of 45.86 lakh houses in urban areas since it came to power in 2014, recording an increase of around 240 percent as compared to that sanctioned in the UPA government's 10-year tenure, as per official data. According to the housing and urban affairs ministry data, around 13.45 lakh houses 
were approved during the UPA I and II under two schemes - Jawaharlal Nehru National Urban Renewal Mission (JNNURM) and Rajiv Awas Yojana (RAY). After the NDA government came to power in 2014, 45.86 lakh houses have been sanctioned under this flagship program - Pradhan Mantri Awas Yojana (Urban) as quoted by a senior official with data. Under the PMAY (U), the government focuses on constructing around 1.2 crore houses for urban poor by 2022(PTI, 2018).

- According to Transparency International's Corruption Perceptions Index (CPI) 2018, India's rank increased by three points. India was placed at 78th, while China was at 87 th and Pakistan 117th. Since 2015, the average CPI of India has been stable at 78.5. The NDA made upgradation in anti-corruption laws. It ordered the Prevention of Corruption (Amendment) Act 16 of 2018 (which makes offering bribe as a criminal offence, creates corporate criminal liability and extends the definition of criminal conduct), and the Benami Transactions (Prohibition) Amendment Act, 2016 (which provides for expedited procedures to deal with property held for a beneficial owner where the same is untraceable or fictitious), etc. (Financial Express, 2019).

- During the UPA government the expenditure on education was Rs. 65,867 crore, which increased to Rs. 79,868 crore during NDA regime in 2017-18. During the UPA government's regime (2013-14), the total universities in the country stood at 723 which were expanded to 799 in the NDA regime (2016-17), indicating 76 new universities established during NDA regime. During UPA's time (2013-14), the total numbers of schools in the country were $15,18,160$ which have increased to $15,22,346$ during the reign of NDA, i.e. the total numbers of 4186 new schools have been added. Also during UPA time (2013-14), the total colleges in the country were 36,634 which rose to 39071 during the NDA regime (2016-17) i.e. 2437 new colleges were established. (Singh, 2017).

- The NDA-II's SBM is a reconstructed version of the UPA's Nirmal Bharat Abhiyan (NBA) which came up from NDA-I"es Total Sanitation Campaign (TSC), though the big difference with SBM has been the speed and scale of its implementation. For example, the pace of toilet construction in SBM is nearly two times that of the NBA. The NDA-II has significantly brought more resources to sanitation as well. On an average, NDA-II assigned $0.5 \%$ of its annual budget to construction of toilets against UPA's $0.1 \%$. And the individual subsidy for toilet 
construction has also increased: the SBM provides Rs.12,000 for every toilet as compared to Rs.10,000 under NBA and Rs. 4,500 in the TSC. The data from SBM shows that $99 \%$ of the country has access to toilets (up from $40 \%$ in 2014), and all except five states are open defecation free. NDA - II has shown comparatively much better performance in this sector as compared to UPA (Padmanabhan et al., 2019).

- Taking cognizance of the role of cleanliness in healthy living, and to accelerate the efforts to achieve universal sanitation coverage, the NDA government launched the Swachh Bharat Mission on 2nd October 2014. As per the baseline survey conducted by the Ministry of Drinking Water \& Sanitation, 55 crore persons were defecating in open in October 2014, which declined to 25 crores in January 2018; at a much faster rate, compared to the trend noticed before 2014 (The Economic Times, 2019).

- In the year 2013-14, the UPA government spent only $1.2 \%$ of GDP on health, which rose to $1.4 \%$ in 2016-17. The NDA Government has made a provision of Rs. 48,878 crore for the health sector for the year 2017-18, which was increased from Rs. 37,330 crore in the year 2013-14. Also, the current government, NDA declared a new National Health Policy in 2017 which aims at shooting up the average age from 67.5 years to 70 years by 2025 , with a target of $2.5 \%$ of GDP on health care (Singh, 2017).

- In the financial year 2015-16, approximately 1.35 lakh jobs were generated in the country against 4.20 lakh during the UPA regime. However, in 2016-17, 2.13 lakh new jobs were generated, in which main contributing sectors were service, manufacturing, and trade. At present, more than $30 \%$ of the youth aged between 15 to 30 years are either unemployed or not taking the training in the country. So it may be said that the overall performance of the Modi Government is not up to the mark in terms of employment generation (Singh, 2017).

- When there is an increase in incomes there is also an increase in power consumption, which makes it a good proxy for a state's progress. In this aspect, the BJP not only holds the top three spots but does so with an emphatic margin. By comparison, three of the six Congress states dropped even below the national average, with Haryana being the worst (Raja, 2013).

- Agriculture growth during the UPA regime was $4.01 \%$, which rose to $4.83 \%$ in 2016-17. In 2013-14, the food grains production in the country stood at 2650 lakh tonnes which are estimated to be around 273 lakh tonnes in 2016-17. NDA government has targeted a loan of Rs 10 lakh crore to farmers this year, while in 
UPA regime farm loan of 7.11 lakh crore was issued (Singh, 2017).

\section{CONCLUSION}

The paper investigates the impact of change in the ruling party on the governance and socioeconomic parameters in the Indian context. In order to achieve this, the paper has attempted to formulate Governance and socio-economic indices. It has been found that the Governance matters but good governance is better. Further, the paper tried comparing the two most vying governments; NDA and UPA on the scale of good governance by analyzing their performance as a ruling party in terms of control of corruption, effectiveness, rule and regulation, accountability, political stability and absence of violence in their respective regimes that is [(1998-2004) and (2015-2018)] and 2005-2014 respectively. According to the research and data comparison, the governance index is maximum in the time period 2016-2017, where NDA was the ruling party and minimum in the time period 2011-2012, ruling time period of UPA. In an economy like India where societal problems such as access to electricity, unemployment, sanitation, gender inequality, education, rising population, etc. are present copiously, welfare of its people becomes a vital factor in determining performance. Therefore, the paper also compared the socio and economic performance by analyzing the socio-economic index of NDA and UPA, and correspondingly with the help of data it was found that the average growth rate of the socio-economic index of NDA is greater than that of UPA.

\section{CONFLICT OF INTEREST STATEMENT}

The authors declare that there is no conflict of interest.

\section{SOURCE OF FUNDING}

We would like to thank Maitreyi College, University of Delhi for funding the expenses of this research project.

\section{ACKNOWLEDGEMENTS}

First and foremost our sincere gratitude goes to Dr. Haritma Chopra, Principal, Maitreyi College, University of Delhi for giving us the opportunity and the right platform to conduct the research under the guidance of supportive mentors. At last, our appreciation also goes to our supportive families whose moral and material support enabled us to successfully conduct and complete this study. 


\section{REFERENCES}

Babalola, S.J. \& Aminu, U. (2011). Fiscal policy and economic growth relationship in Nigeria. International Journal of Business and Social Science, 2(17), 244-249.

Brewer, G.A., Choi, Y. \& Walker, R.M. (2007). Accountability, corruption and government effectiveness in Asia: an exploration of World Bank governance indicators. International Public Management Review, 8(2), 204-225.

Dessie, B. (2018). Determinants of Good Governance: Evidence from Some Selected Public Institutions in Jimma City. Science Journal of Business and Management, 6(6), 100106.doi: 10.11648/j.sjbm.20180606.11

Dewan, E. \& Hussein, S. (2001). Determinants of Economic Growth (Panel Data Approach). Working Paper (01/04). Economics Department Reserve Bank of Fiji. Available at: http://www.rbf.gov.fj/docs/wp2001-04.pdf

Emara, N. (2016). The Impact of Governance Environment on Economic Growth: The Case of Middle Eastern and North African Countries. Journal of Economics Library, 3(1), 24-37.

ETMarkets.com. (2019). UPA vs NDA: This scorecard shows who delivered more when in power. The Economic Times. Available at: https://economictimes.indiatimes.com/markets/stocks/news/2009-19-what-workedwhat-didnt-for-indian-economy/articleshow/68795143.cms

Financial Express (2019). Corruption and NDA: Are we getting rid of corruption? The Financial Express, Available at:https://www.financialexpress.com/opinion/corruption-and-nda-are-we-gettingrid-of-corruption/1480672/

Gisselquist, R.M. (2012). Good governance as a concept, and why this matters for development policy (No. 2012/30). WIDER Working Paper, Available at: https://www.wider.unu.edu/sites/default/files/wp2012-030.pdf

Kaul, V. (2019). Manmohan Singh Vs Narendra Modi: The Real India Growth Story. Livemint, Available at: https://www.livemint.com/politics/policy/manmohan-singh-vsnarendra-modi-the-real-india-gdp-growth-story-1555034270688.html

Kowalski, E. (2000). Determinants of economic growth in East Asia: A linear regression model. Honors $\quad$ Projects, Available at: https://digitalcommons.iwu.edu/cgi/viewcontent.cgi?article=1051\&context=econ honproj

Miljkovic, D. \& Rimal, A. (2008). The impact of socio-economic factors on political instability: A cross-country analysis. The Journal of Socio-Economics, 37(6), 24542463. 
Padmanabhan, V. \& Alexander, S. (2019). Under NDA, More Toilets, Less Open Defecation. Livemint, Available at: https://www.livemint.com/news/india/under-nda-moretoilets-less-open-defecation-1552842931107.html

Pourgerami, A. (1988). The political economy of development: A cross-national causality test of development-democracy-growth hypothesis. Public choice, 58(2), 123-141.

Press Trust of India (2018). 240 per cent increase in urban house approval under NDA govt. The Economic Times, Available

at:https://economictimes.indiatimes.com/news/economy/policy/240-per-centincrease-in-urban-house-approval-under-nda govt/articleshow/64245092.cms?from=mdr\#:\%7E:text=Construction\%20of\%208.0 4\%201akh\%20houses, official\%20said\%20quoting\%20the\%20data.

Press Trust of India (2019). 9.16 Cr Toilets Built, 5.5 Lakh Villages Declared ODF Since 2014: Govt. The Economic Times, Available at: https://economictimes.indiatimes.com/news/politics-and-nation/9-16-cr-toiletsbuilt-5-5-lakh-villages-declared-odf-since-2014-govt/articleshow/67886006.cms

Raghotham, S., Das, G. \&Nayak, V. (2019). Modi'S 5 Years: A Report Card. Deccan Herald, Available at: https://www.deccanherald.com/specials/sunday-spotlight/modi-s-5years-a-report-card-726064.html

Rai, S. (2019). Minorities safer under Modi regime than under 10 years of UPA rule, proves RTI response. Available at https://www.mynation.com/news/minorities-saferunder-modi-regime-than-10-years-upa-rule-proves-rti-pkt7ko

Raja, D.J.S. (2013). Congress versus BJP: Who has fared better in the last five years. The Economic Times, Available at:https://economictimes.indiatimes.com/news/politicsand-nation/congress-versus-bjp-who-has-fared-better-in-the-last-fiveyears/articleshow/21970277.cms

Singh, H. (2017). UPA Vs NDA Government: Comparison Since 2014 To2017.Jagranjosh.com, Available at: https://www.jagranjosh.com/generalknowledge/upa-vs-nda-government-comparison-since-2014-to2017-1497266267-1

Srivas, A. (2016). Twenty Crore Bank Accounts Opened: Where Does Jan DhanYojana Go From Here? An Explainer. The Wire, Available at https://thewire.in/banking/twentycrore-bank-accounts-opened-where-does-jan-dhan-yojana-go-from-here-anexplainer

The World Bank (1992). Governance and Development. Retrieved from website http://siteresources.worldbank.org/INTWBIGOVANTCOR/Resources/174047911 49112210081/2604389114969 9431307/edouardpresentation_munich_inwent.pdf. Accessed 27 May 2016 


\section{APPENDIX \\ Trends in indicators of governance and socio-economic parameters}

The graphs given in this appendix show the trends and patterns of the variables that are considered in formulating governance and socio economic index in the study for Indian economy. The data sources are the World Bank, Reserve Bank of India (RBI) and UNDP.

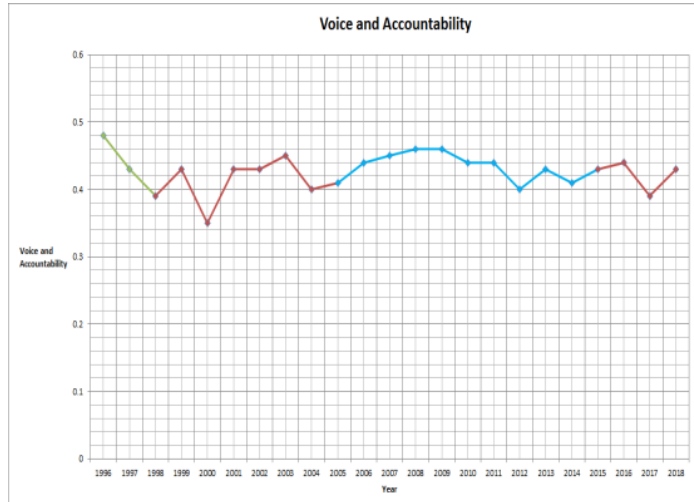

Figure 5: Voice and Accountability

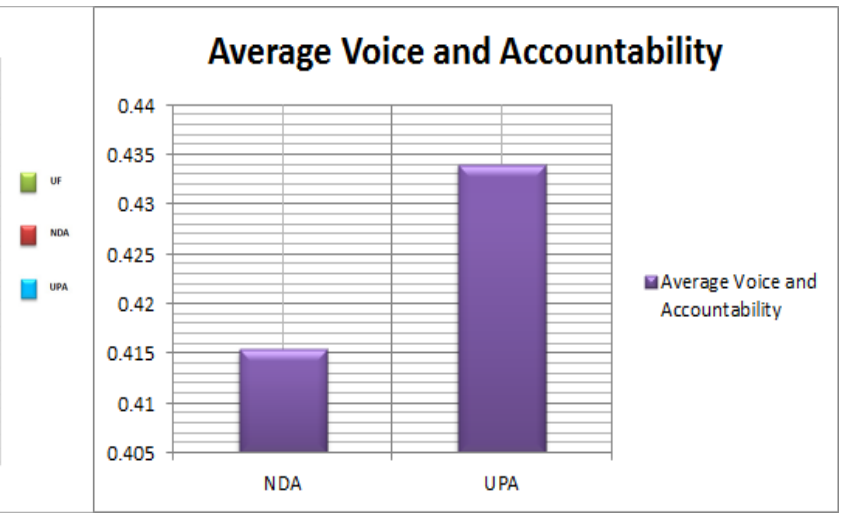

Figure 6: Average Voice and Accountability
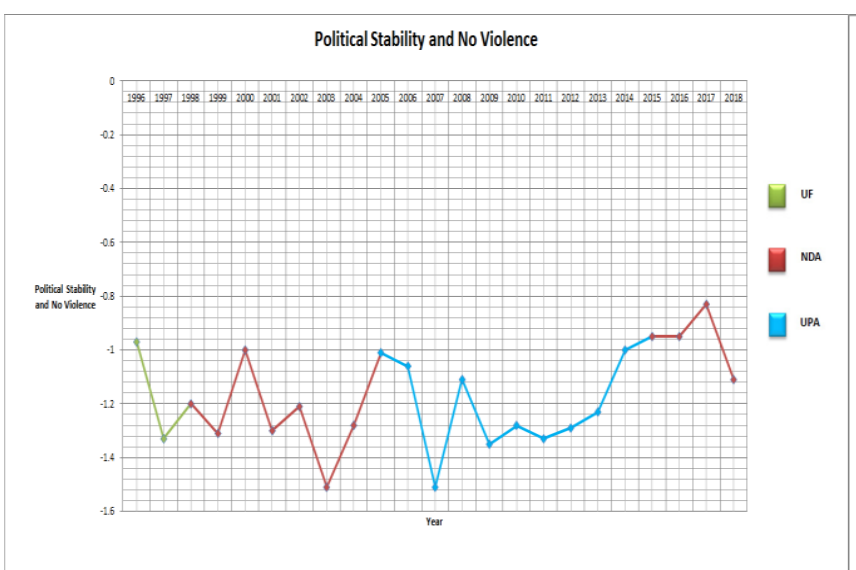

Figure 7: Political Stability and No Violence

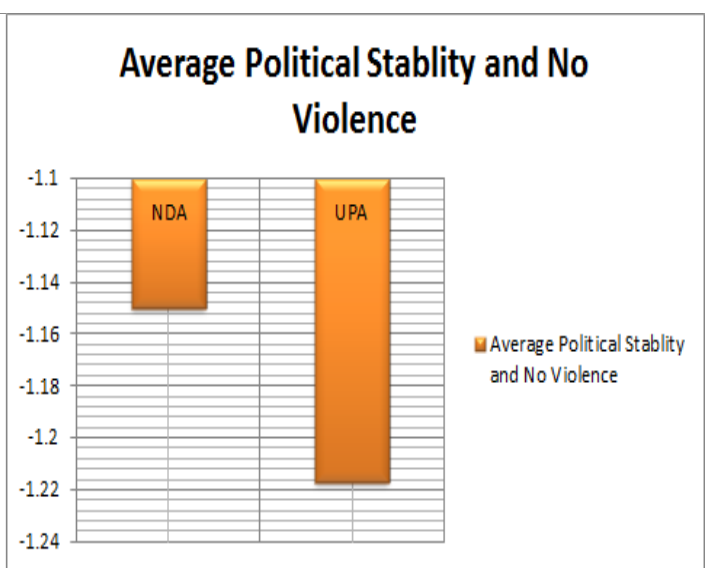

Figure 8: Average Political Stability and NoViolence

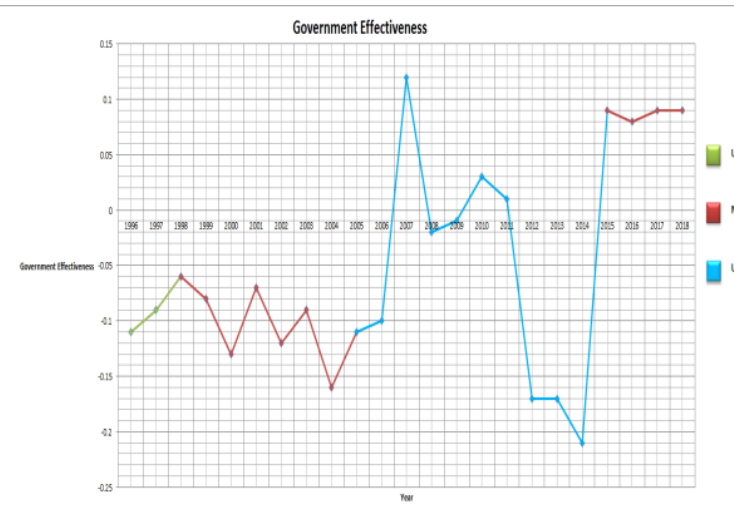

Figure 9: Government Effectiveness

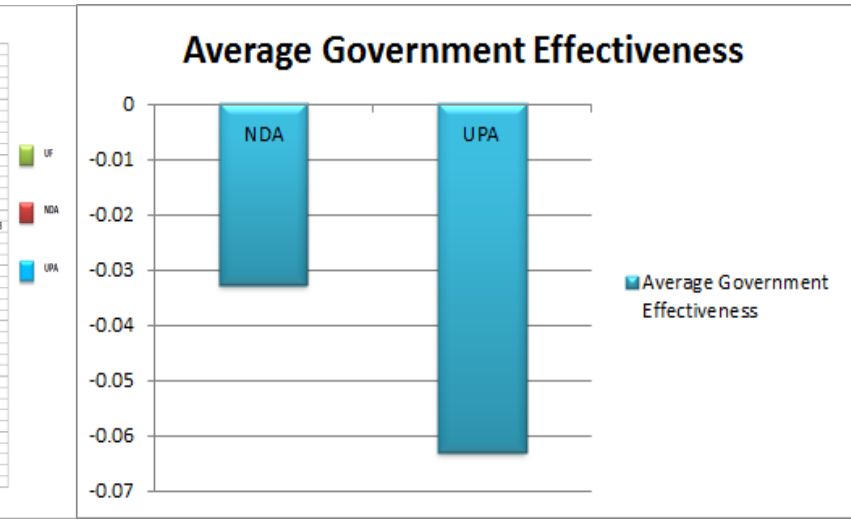

Figure 10: Average Government Effectiveness 


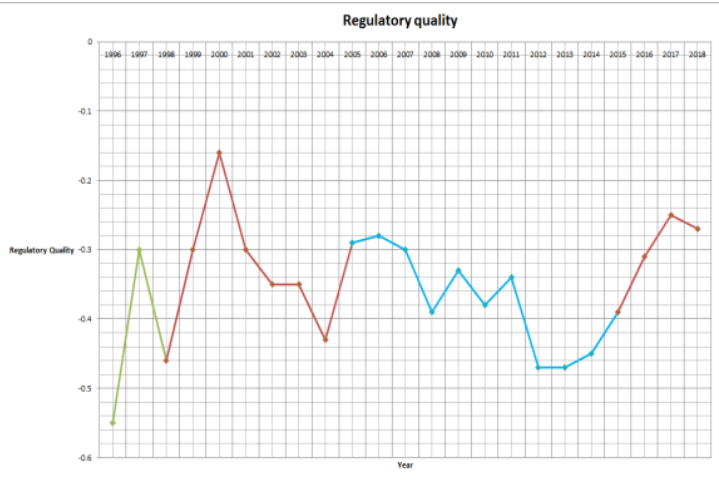

Figure 11: Regulatory Quality

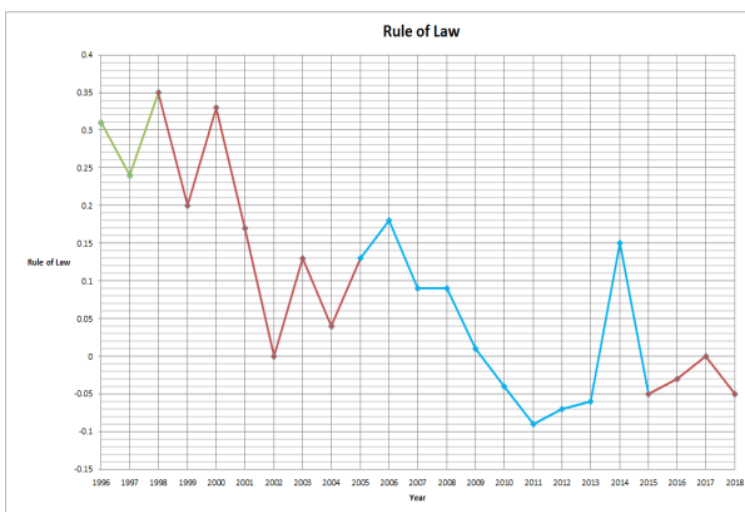

Figure 13: Rule of Law

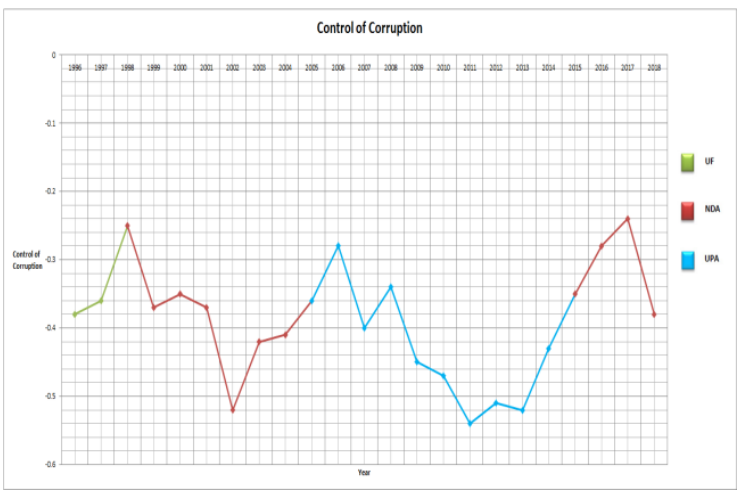

Figure 15: Control of Corruption

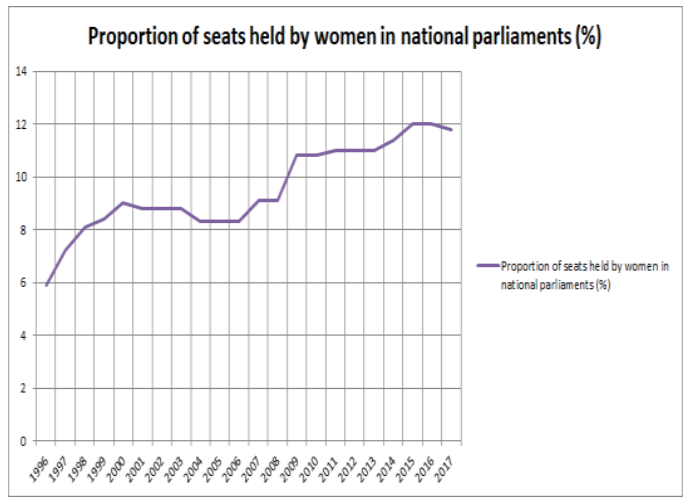

Figure 17: Proportion of seats held by women in national parliaments

\section{Average Regulatory Quality}

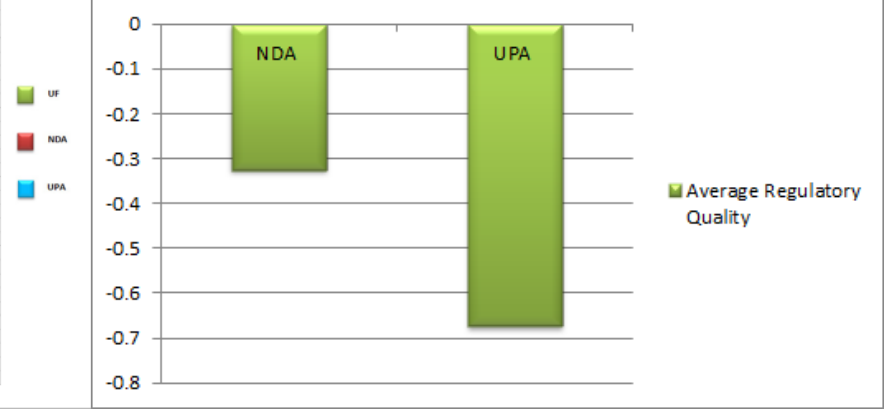

Figure 12: Average Regulatory Quality

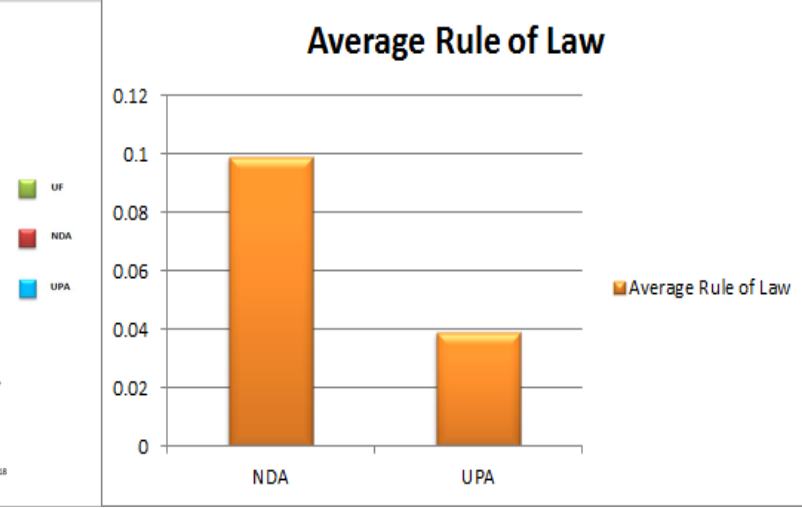

Figure 14: Average Rule of Law

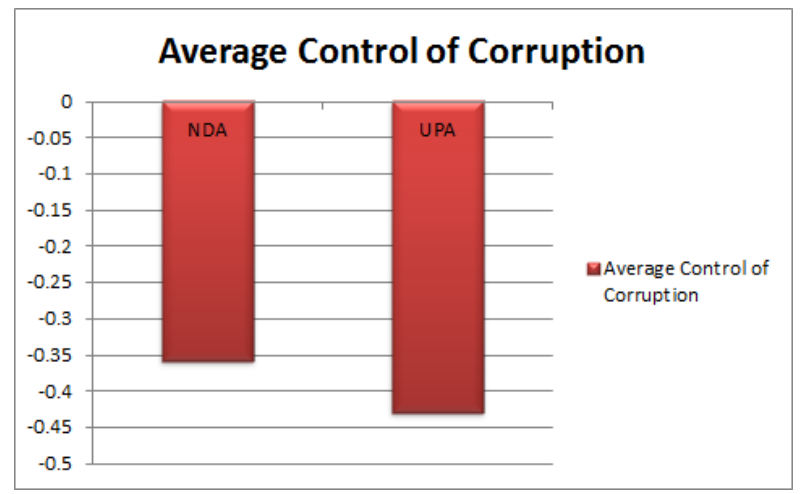

Figure 16: Average Control of Corruption

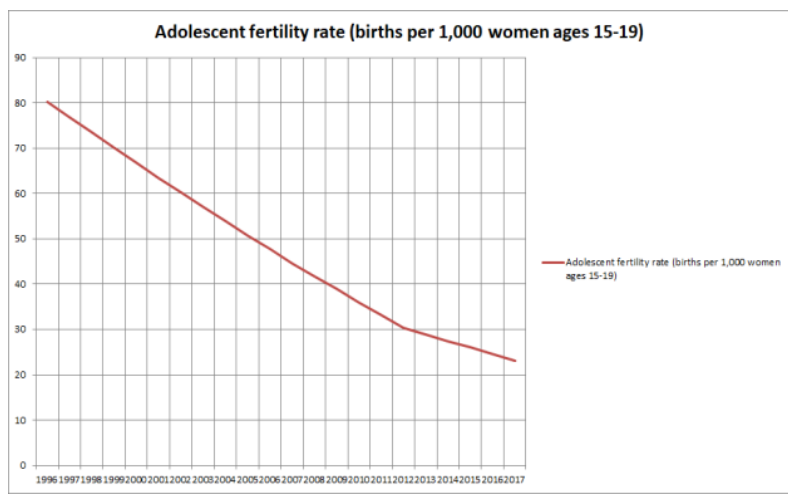

Figure 18: Adolescent fertility rate 


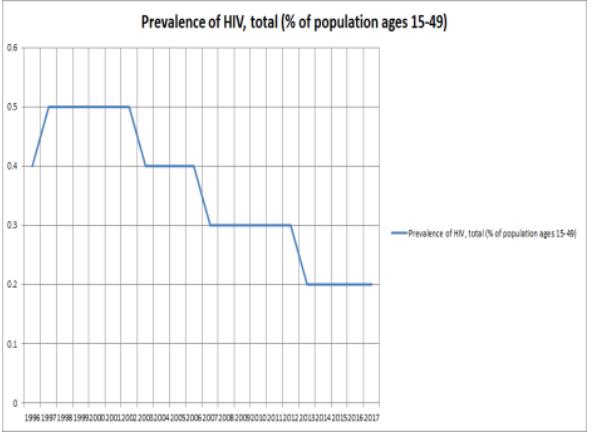

Figure 19: Prevalence of HIV, total

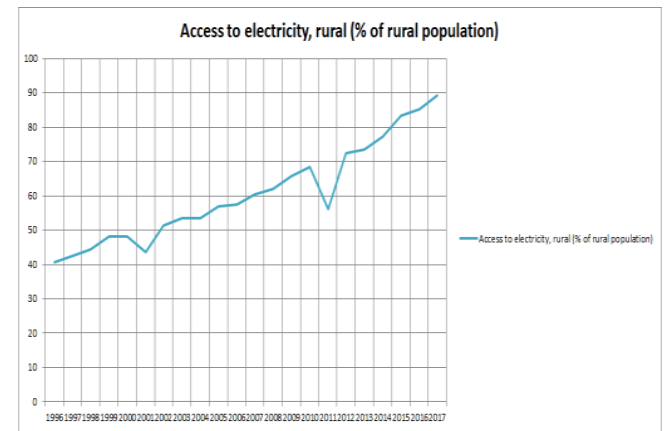

Figure 21: Access to electricity, rural

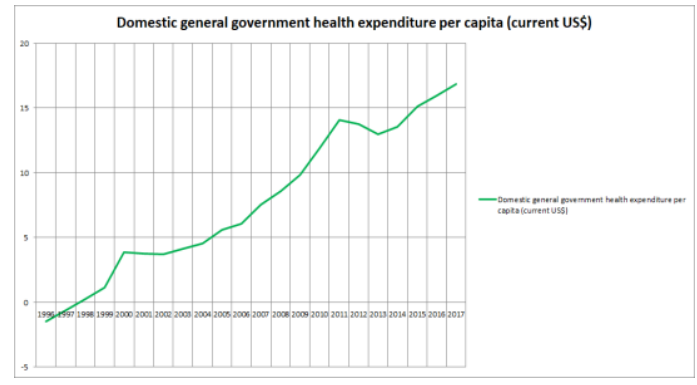

Figure 23: Domestic general government health expenditure per capita

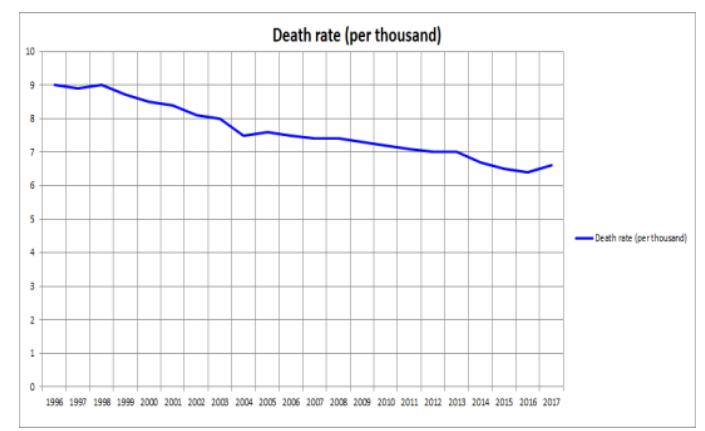

Figure 25: Death rate (per thousand)

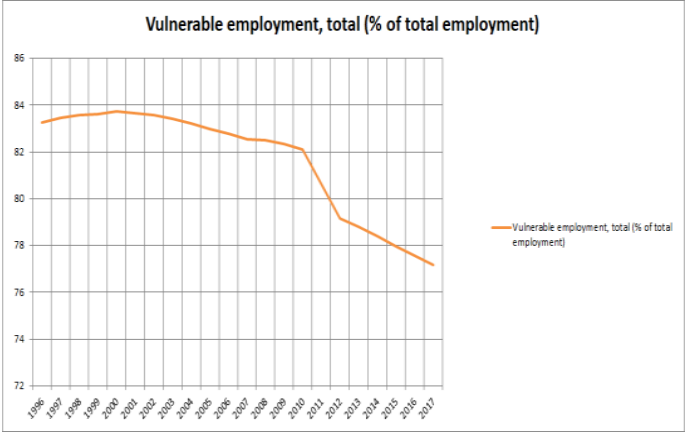

Figure 20: Vulnerable employment, total

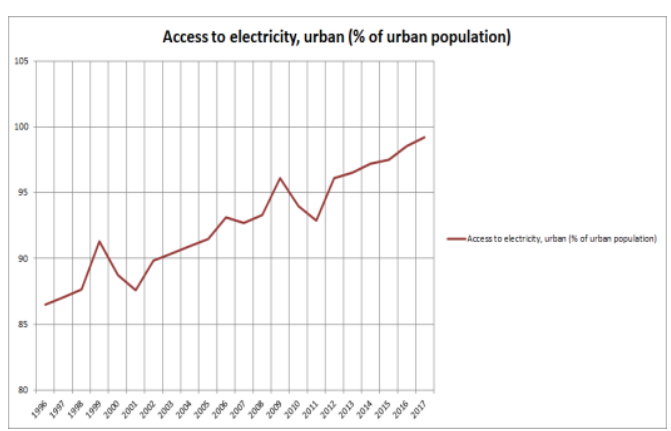

Figure 22: Access to electricity, urban

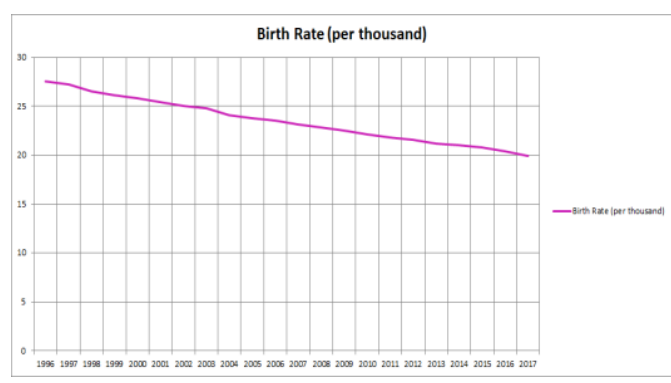

Figure 24: Birth rate (per thousand)

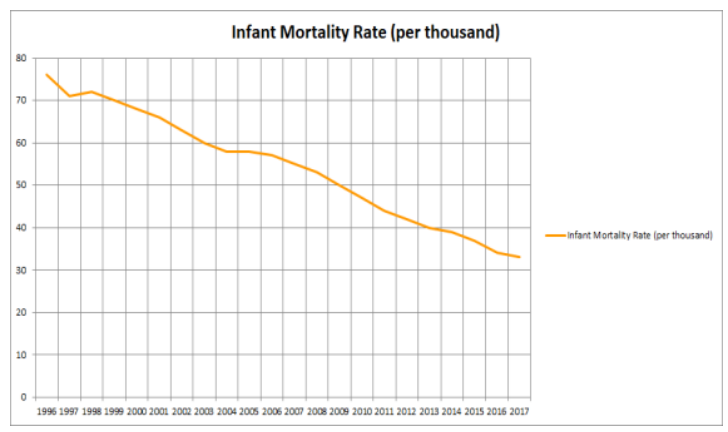

Figure 26: Infant mortality rate (per thousand) 


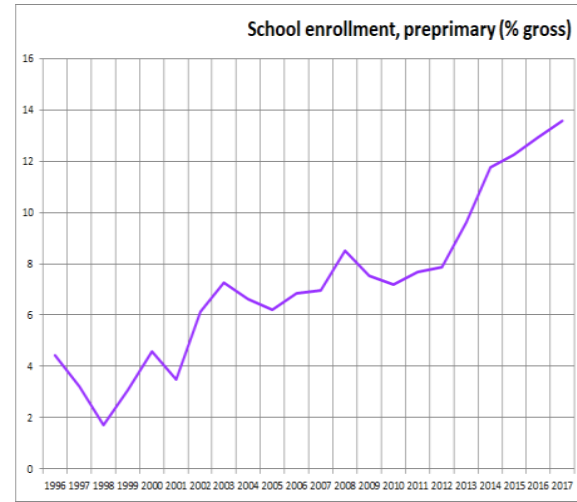

Figure 27: School enrollment, preprimary (\%)

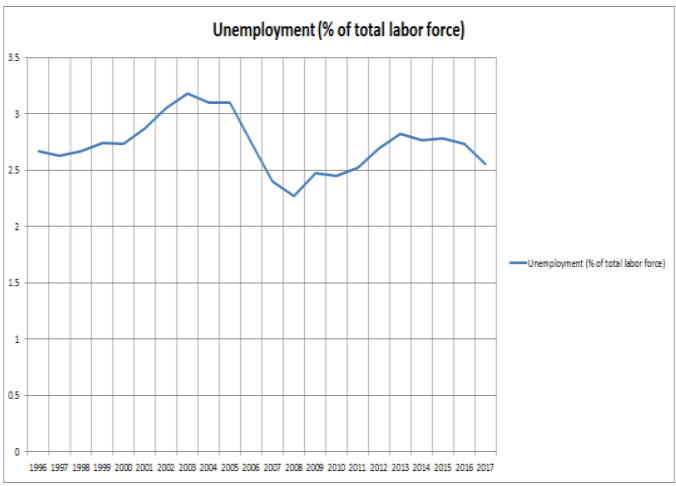

Figure 29: Unemployment (\%)

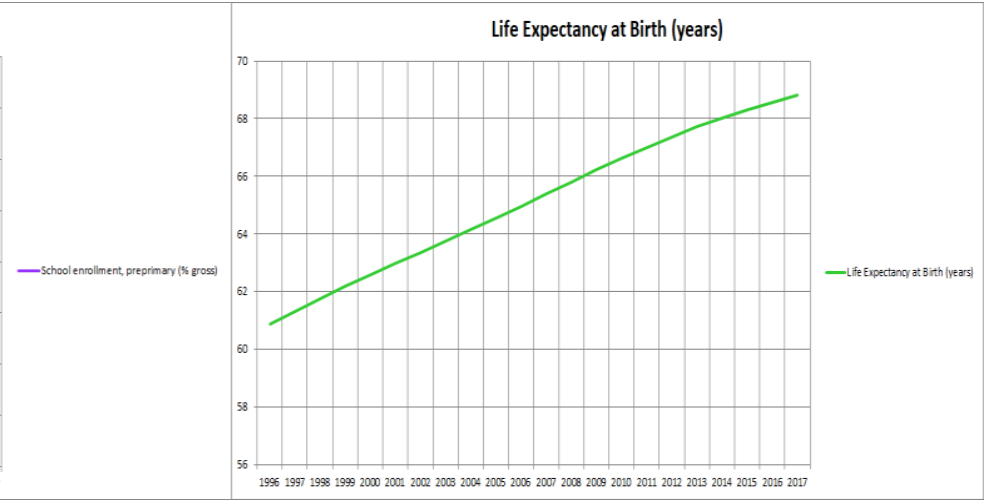

Figure 28: Life expectancy at birth (in years)

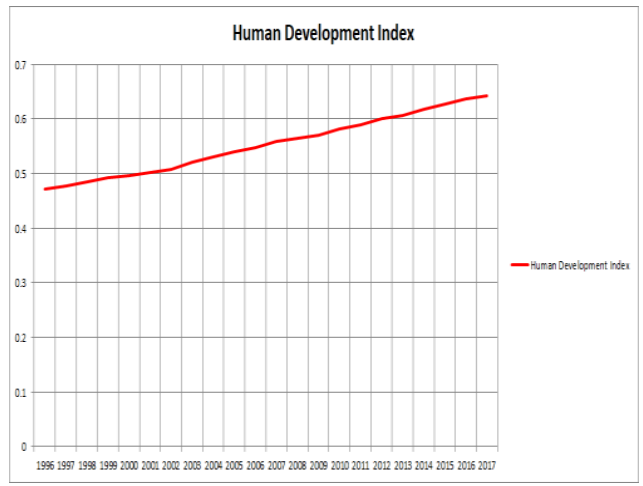

Figure 30: Human development index

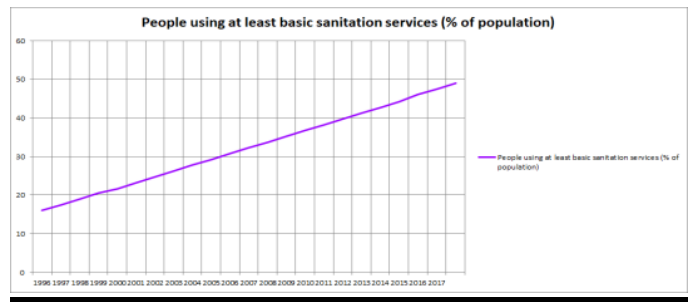

Figure 31: People using at least basic sanitation services

How to cite this article: Chand, N., Kataria, N., Kashyap, A., Sood, A., Sharma, D., Arora, N., Shikha \& Raj, Y. (2020). A Comparative Analysis of Socio-Economic and Governance Dimensions of Political Regimes in India. Vantage: Journal of Thematic Analysis, 1(1): 105124.

DOI: https://doi.org/10.52253/vjta.2020.v01i01.10

(C) The Author(s) 2020.

This work is licensed under a Creative Commons Attribution 4.0 International License which permits its use, distribution and reproduction in any medium, provided the original work is cited. 